\title{
Cultural Sexism and the UK Higher Education Sector
}

\author{
Heather Savigny \\ Leicester Media School, De Montfort University, UK \\ heather.savigny@dmu.ac.uk
}

Accepted and forthcoming in Journal of Gender Studies (2018)

\begin{abstract}
Despite the advances of the feminist movement, and wider structural legislative interventions, women remain under-represented at senior levels within academia and (some) women still experience both direct and indirect forms of discrimination throughout their careers. This article seeks to understand why this might be the case, and what, if anything we can do about it.

Using qualitative interview data which gives voice to women's experiences, this article explores the cultural dimensions which serve to reinforce women's structural disadvantage within the academy. Drawing upon these empirical data and informed by reflections on the notion of 'hegemonic masculinity' (Connell, 1983) in a neoliberal environment, this article contends that 'cultural sexism' provides a vocabulary through which to make sense of this structural disadvantaging. It is argued here that an understanding of the 'ordinariness' of cultural sexism (Savigny, 2017) means we can both 'raise consciousness', and, explore emancipatory opportunities where cultural resistance and change might be possible.
\end{abstract}

Keywords: Cultural sexism; UK Higher Education; neoliberalism; hegemonic masculinity.

Introduction: cultural sexism in the UK Higher Education Sector

When your head of department says to you in a departmental meeting 'the thing that you don't understand [the word 'dear' is implied] that the reason we don't have any women here [straight away invisiblising you!] is that women just don't do [your discipline]. And that's why there are no female Professors (lecturer) 
When your senior male colleague comes up behind you, puts his hands on your waist, and whispers in your ear, 'this is not sexual harassment' (early career researcher)

The first story here was told to me a number of years ago by an early career researcher. Not only did this statement render her feeling completely invisible in front of her department of male colleagues, and devalue her own contribution to her discipline, she also was able to demonstrate that his comment about the absence of Professors in the field was untrue. The second comment speaks to not only experiences of sexual harassment that women in Universities continue to endure, but to an assumption of female availability for sexual purposes that seems to pervade the academy. The viral \#MeToo (and its academic counterparts \#MeTooPhd/\#MeTooAcademia) have continued a trend of women speaking back to those who abuse and enact, what Laura Bates' powerful project termed, 'Everyday Sexism'.

Clearly naming and shaming is powerful. The focus on individual experiences is important, not only because of the ways in which individual women can have their voices heard, but in also challenging and disrupting those wider assumptions that are made about the role of women within society. The actions of individual women acting collectively (in the Everyday Sexism project, following the Weinstein scandal, and indeed, in the history of feminist activism and thinking) has clearly had several significant effects. First, it raises the profile of women's structural disadvantage, as something that we need to talk about when we think about how our society works. Second, speaking up and out can be empowering for the women affected, in the act of having voice, and knowing that voice is being heard; in shattering the silence, women can be powerful. However, we also need to ask the questions: how and why is it that women are in the position that they need to speak up and out in the first place?

The Domestic Violence, Crime and Victims Act (2004) reminds us that there is legislation in place to protect women from abuse, harassment and assault. Between 2009 and 2015 in the UK 3 women per week were killed by a man (Women's Aid, 2018) and the World Health 
Organisation (2017) tells us that 1 in 3 women worldwide has suffered a form of sexual abuse and harassment. At the same time legislation now exists that provides for women to be afforded equality. Equal Opportunities legislation states that women have equal access to employment. Equal Pay legislation prescribes that women be paid the same as men. And yet despite these structural interventions by the state, women are still underpaid and underpromoted. The aim of this paper is to ask why this might be the case, using the UK Higher Education sector as a case study. If there are structures in place to prevent discrimination against women, then why do these structures fail? In essence, this article asks questions about the role of culture in undermining structural interventions.

Cultures and structures provide a framework to guide individual behaviour and play a fundamental role in shaping norms, values and 'standard operating practices'. In this article I want to reflect on the ways in which the norms of behaviour within UK Universities are highly gendered, and I use the experiences of women academics to examine the cultural structures of power. Using the UK University sector as a case study, I develop the concept of cultural sexism as a mechanism to explore the cultural conventions which shore up and operationalise patriarchal structures rather than challenge them. Sexism in Higher Education is something that has been well documented (for review of this literature see Amery et al, 2015). Higher Education in the UK, is also situated in an increasingly normalised neoliberal context (cf. Doherty, 2011; Collini, 2012). This neoliberal context as Gill (2009) observes, creates 'hidden injuries' for the academic within. But this neoliberal academic is not one that is gender neutral, and I argue that gendered experiences both precede, and are exacerbated by, the neoliberal context. In this neoliberal environment, individuals are prioritised, consumerism is entrenched as emblematic of the notion that markets provide the solutions to social and political problems. But this neoliberal agenda also requires the performance of a series of 
masculinised traits. And this is the backdrop: neoliberalism has been embraced in the HE environment, in which we are defined and recognised first through our gender, second as neoliberal subjects. As such, I argue that it is at this intersection of neoliberalism and patriarchy, where constructed gender relations meet political ideology in the academy, where the further 'hidden injuries' lie. As such, cultural sexism is comprised of discourses of neoliberalism, which take shape as neoliberal hegemonic masculinity, and are operationalised and appear as both internalised misogyny, and isolation as a mechanism to discipline women.

\section{The HE Sector as a case study}

Despite the introduction of Equal Opportunities legislation in 1975, women remain under represented at senior levels within across the HE sector. Women are $35 \%$ more likely to undertake an undergraduate degree than men (Weale, 2016) and yet men are over represented in the higher echelons of the profession. In the UK there are 4,775 female Professors out of 19,975 . Men constitute $76 \%$ of the professoriate despite being $55 \%$ of the academic staff (HESA 2017). Only 30 of these female Professors are BAME (Runnymede Trust, 2015; Black British Academics, 2016 cited in Mirza, 2017; for institutional breakdown see Solanke, 2017). Only 36 of the world's top 200 Universities have female leaders (Bothwell, 2017) and in the UK only 2 female Vice-Chancellors are BAME (Khan, 2017). The Equal Pay Act was introduced in the UK in 1970. But, in the UK female academics earn $11.3 \%$ less than men (and in some institutions this widens to $27 \%$ (Grove, 2015). UCU data shows a wider gender pay gap of $18 \%$ in UK academia and in 154 British Universities, women are paid less than men, and that there are only 8 institutions where women are paid the same or more.

When we see these statistics, we might ask, why is female advancement so slow, despite the legislative measures that are in place? Attention has been paid to the ways in which women's under-representation is a structural issue (Bird, 2011; van den Brink \& Benschop, 2012); a 
cultural issue (Knights \& Richards, 2003; Savigny, 2014); an organisational issue (Parsons \& Priola, 2013); or an issue that individual women themselves can resolve in the Sheryl Sandberg (2013) 'Lean In' style. And yet, women academics are 'othered' (Eveline \& Booth, 2004) in relation to the masculine 'norm' of what it means be an academic. Much of the literature focuses on women themselves as disadvantaged in both research and managerial careers (Park, 1996; Parsons \& Priola, 2007; van den Brink \& Stobbe, 2009) and the gendered nature of institutional structures (van der Brink \& Stobbe, 2009; Bird, 2011). Benschop and Brouns argue (2003) that we cannot study organisations without paying attention to gender; more than this, as Leonard observes, we need to be cognisant of the role that Universities play in 'actively constitut [ing] gender' (Leonard, 2001: 4). But whether the focus is on the individual or the organisational or legislative structures, the argument is that they need to be supported by a cultural context conducive to women's advancement.

Hearing women's voices and experiences is powerful in enabling us to make sense of the ways in which 'cultural sexism' plays a key role in women's marginalisation (Savigny, 2014, 2017). This can fall around a variety of areas: the so called 'leaky pipeline' has cultural roots; we see women's scholarship devalued and subjected to levels of defence not necessarily required in other subject areas (Jenkins, 2014; Wright, 2014). Women are less likely to have their work cited by other scholars (Ferber, 1988; Maliniak et al, 2013) and less likely to be invited in the first place, to speak at conferences and seminars (Yong, 2017). These experiences become even more pronounced for women of colour (Patton, 2004; Sang, 2017; Gabriel \& Tate, 2017). These 'micro aggressions' form part of the backdrop to a diversity of women's lived experiences within the academy (cf. Sang, 2016; Gabriel \& Tate, 2017). These are not issues that solely affect white women; as has been widely noted, analysis must be intersectional (cf. Crenshaw, 1989). As Allen (1992) has argued, universities are also organisations which collectively reproduce a status quo, which is not only male but is 'rooted in an unfair system of racial stratification' (1992: 42). 
Understanding the processes which take place in the contemporary environment facilitates forms of resistance and enables us to ask: how it is that the status quo is reinforced. Patriarchal structures provide the platform for sexism; for sexism to work misogyny must become internalised. In a neoliberal system, where competition rules and individuals are pitted against each other, rather than working towards a collective endeavour, sexism helps individuals gain advantage over their rivals. In what follows I develop a conceptual framework for making sense of this cultural embedding of the marginalisation and devaluing of women which in turn may be seen as contributory to the glacial progression of women in the UK Higher Education sector.

\section{Cultural sexism: a conceptual framework}

Cultural sexism is a term which can be used to enable us to understand the failure of legislative and structural interventions. Cultural sexism draws our attention to the micro-level features of everyday life, as cumulatively experienced by women, which actively work to undermine the opportunities for progress afforded by structural interventions such as legislation or institutional policy. Cultural sexism is the 'drip drip drip' of daily experiences, which serve to marginalise, silence, damage self-confidence and destroy belief in the ability of women. It is the very ordinariness of sexism which reflects the internalisation of hegemonic masculinised discourses (see also Savigny, 2014; 2017).

The data presented in this article is drawn from over 70 interviews that I have undertaken with women in UK academia. They were both formal and informal, undertaken through calls in women's networks and women's conferences. I spoke to women in person, by telephone and by email. Women I spoke to were located across the academic spectrum, in the from the sciences, social sciences and arts and humanities, in Russell Group, pre- and post- 92 institutions. What has been noticeable is the lack of difference the institution type or 
discipline makes to these experiences. Given the sensitive nature of the conversations we were having, and respecting the importance of anonymity and confidentiality, I made notes and kept a journal detailing these women's experiences as a basis from which to identify themes and trends. In this I draw from these qualitative data to give voice to these experiences, in order to reflect not just on what is happening, but why it is happening and what we might do to change this.

What I have heard repeatedly over the years are stories of isolation, and the negative consequences these sexist cultures have had on women's beliefs, abilities, and their desire to stay within the academy. These experiences, I argue, speak to the ways in which sexism becomes instantiated, routinized and normalised through daily cultural practices. To illustrate this, I use excerpts from these interviews in italicised quotes below. I use the form 'you' to enable the reader to connect directly to the experience (consistent with feminist theorising cf. Ahmed, 2017). I argue that contemporary cultural sexism relies on the discursive embedding and circulation of hegemonic masculinity, and this is characterised in contemporary neoliberal terms. In this sense, isolation and the internalisation of misogyny become ways in which cultural sexism is further operationalized.

\section{Neoliberal hegemonic masculinity}

Connell (1983) first coined the term 'hegemonic masculinity' to denote the ways in which particular versions of masculinity become normalised. Connell's work was concerned with wealth and social status as a marker of hegemonic masculinity, and how particular conceptions of masculinity came to stand for the 'male norm'. Connell (1995) argued that while hegemonic masculinity described the ways in which particular versions of masculinity became dominant and accepted as the status quo, this also contained the possibility that other types of masculinities could be realised. Hegemonic masculinity, takes issue with the 
notion of essentialising assumptions about what it means to be 'a man'. Rather the authors argue that just as feminist theorising points us towards a diversity of women, interests and experiences, as such the same holds for men. For example, men who seek to advance the cause of feminism, of white men who oppose racial injustice and working-class men who do not necessarily benefit from the white, middle class, status (see also Carrigan et al, 1987). This widely cited formulation of hegemonic masculinity, became the foundation to think about multiple and complex masculinities. As with other feminist and cultural theorising masculinity was reliant on the inferiority of the feminine 'other' (de Beauvoir, 1997; hooks, 1981).

Connell is keen to point out, that hegemonic masculinity is about a system of privilege rather than individual men (many of whom also are uncomfortable with this positioning), and indeed it may well be that only a minority of men who enact it (Tarrigan et al, 1987). Despite this being something that does not rely on significant numbers of men to actively enact, what the notion of hegemonic masculinity enables us to reflect upon is how 'particular groups of men inhabit positions of power and wealth, and how they legitimate and reproduce the social relationships that generate their dominance' (Carrigan et al, 1987: 92). Kimberle Crenshaw drew out attention to the ways in which race, gender and class interact to generate multiple intersectional sites of oppression (1991). And perhaps to fully appreciate the complicity of the nature of hegemonic masculinity, it is useful to reframe it as white hegemonic masculinity. This foregrounding reminds us that race also plays a role in legitimating the masculine 'norm'. Contemporary hegemonic masculinity takes a particularly neoliberal form in the UK Higher Education context as the neoliberal agenda is one that has now come to define the UK university setting. Students are positioned as 'consumers'; fee payers who expect a service, not an education (Scullion \& Molesworth, 2016). Vice-Chancellors position themselves as CEOs and compare themselves to business and industry leaders to justify their salaries, rather than as public sector workers (Lorenz, 2012). The shift to a neoliberal agenda in HE and the 
ways in which this has fundamentally impacted the ways in which education is conceived, no longer as a 'good' in its own right, but in material, economic terms has been widely discussed as an issue for the sector (Collini, 2012); as have the economic and ideological tools used to embed this agenda (Lorenz, 2012). The embedding of neoliberalism has served to induce stress and anxiety amongst academics themselves (Gill, 2009; 2017) which has fundamentally altered working practices within the University (Lorenz, 2012). This embedding of the neoliberal political agenda also serves to reinforce gendered inequalities (Gill \& Donaghue, 2016). And this is underpinned by a layer of cultural acceptance; one which relies on sexism as lived experience and practice.

Neoliberalism has its roots in economic theory and the work of Adam Smith, as well as that of Friedrich von Hayek and Milton Friedman (for thoughtful historical critique see Naomi Klein, 2007). Neoliberalism assumes that markets provide efficient solutions to societal problems; individuals will work to maximise their own self-interest and so, in a competitive marketplace, the theory assumes that the 'best' (most efficient and effective) outcomes will be achieved. Notwithstanding the problematic assumption that all individuals have fair and equal access to the market place, economic theory, and by extension neoliberalism, is premised on assumptions of 'rational' behaviour. Rationality has historically been conceived of as a 'masculine' trait; in contrast to the 'emotional' positioning of the feminine (Longino, 2010; Wacjman, 1991). These assumptions of rationality as an inherently desirable trait, have not only translated into bureaucracy (Pullen, 2006), but also underpin neoliberalism. Underpinning neoliberalism are two fundamental assumptions: individuals are the primary unit of analysis; and for an economic system to function efficiently it must be 'rational'. In this sense we see the embedding of masculine traits at the very heart of the neoliberal system. The concept of hegemonic masculinity helps us unpack how neoliberalism becomes normalised: underpinning a hegemonic discourse of neoliberalism, we witness a version of masculinity encapsulated in the very first principles. In the neoliberal marketplace, rational 
economic 'man' is assumed to be aggressive, competitive and assertive in order for the marketplace to work.

A female early career lecturer's experience illustrates how this individual rationality translates into masculinised practice:

You are really badly bullied by a senior male colleague. He rubbishes your work, the one time he reads it. He doesn't refer to you in front of other colleagues as a researcher, and continues to pile on administrative and teaching tasks. A couple of years ago, you were asked to take on the admin roles of a male colleague in the department, 'temporarily' so he could finish a monograph. This you do, thinking that fairness would mean he would take back his role. But it didn't happen like that. He refused to return to his admin roles, the senior guys were too worried about REF return, well, that seemed to be when it suited, as he was supported to get his REF return, you are still expected to produce one, but while doing the other guy's admin work, who then gets promoted.

In the neoliberal context which privileges the individual, and the market as a solution to social and political problems, it is worth perhaps further unpacking how contemporary hegemonic masculinity can be seen as neoliberal. The quote from the interview above highlights, how an individual might 'rationally' respond in the neoliberal context. Acting collectively clearly is not in the interests of individual advancement. Assumptions of fairness or collegiate working are effectively ruled out in a context whereby individual achievements are attained through competitive means. The market place is assumed to function because of the competition inherent within that market place. In economic theorising this marketplace is filled with individuals whose survival entails success within that competitive environment. The characteristics associated with competition are assertiveness, aggressiveness and an emphasis on working in opposition; individually, rather than collectively. It is not only neoliberal policies which have come to characterise our politics, but political discourses are couched in the language of competition. And we see this very clearly applied in the Higher Education sector. Universities now 'compete' in a marketplace for students and government funding. This move to introduce markets in HE has been accompanied by an ontological sleight of hand. Job adverts reflect the desire for traits such as 'dominance, assertiveness, 
aggressiveness' (Spangsdorf, 2017); traits which are not only traditionally conceived of as male, but also key traits associated with the neoliberal agenda.

We also witness ontological slippage. In positioning Universities as if they were business, Universities have been encouraged to behave as business. In so doing, the collective nature of the search for knowledge and its production is replaced by individual competition and Universities pitted against each other for student recruitment and scarce research funding. This competition reinforces the neoliberal agenda, and crucially, the assumption of desirable traits within that agenda. Aggressiveness and assertiveness, rather than empathy and collegiate and collective working are currently the desirable traits. In this sense we see the neoliberal enterprise privileging and prizing traditional 'masculine' traits. And so by extension contemporary hegemonic masculinity is informed by, and embedded in, an iterative process within the neoliberal agenda.

Hegemony is crucial in maintaining ideological domination. The ways in which something becomes viewed as 'common sense' is a consequence of ideological struggle, contestation and negotiation. According to Gledhill: "hegemony" is won in the to-and-fro of negotiation between competing social, political and ideological forces through which power is contested, shifted or reformed. Representation is a key site in such struggle' (1997: 348). What this tells us is that not only do numbers matter, the descriptive representation of a diversity of women is important. And that the substantive representation, the type of representation, also matters. Within neoliberal hegemonic masculinity, we may see that women are encouraged to behave in ways consistent with that of the prevailing neoliberal hegemonic status quo. This has the potential for two profound consequences. First, it serves to reinforce neoliberal hegemonic masculinity, rather than challenge it, and second, it becomes potentially divisive, isolating and damaging for women (as individuals and as a collective). 


\section{Cultural sexism operationalized/experienced:}

\section{Isolation and the disciplining of women's silence}

In this neoliberal hegemonic masculinised context, isolation has been a key theme to emerge from much of the data. This isolation takes a number of interlinking forms. Women interviewed here often internalised the notion that they could not speak up about their experiences of inappropriate behaviour. This can be a consequence of institutional structures which even where they do exist, do not function to recognise the deleterious consequences of daily micro-aggressions. The isolation that women experience is not only from the institution, but becomes self-fulfilling. Women become reluctant to speak up for fear of repercussions, stay silent, and, so become isolated. Isolation (physical and emotional), can have the effect of marginalising women from the academic communities with which they must engage, both within their institution and in their wider academic communities.

At first, you think you are over reacting. He stands just that little bit too close to you, you know. And then his hand might just brush your leg as you talk. Or he will insist on helping you on with your coat. It makes you uncomfortable but you don't know how to ask him to stop. He touches you inappropriately and when you ask him to stop, he will say, 'hey, I am not sexually harassing you, you know, I thought we were good friends'. He has insisted on collaborative projects with you, outside of your area. You end up doing all the work, he claims first authorship. You have overheard colleagues, when they don't realise you are in earshot, referring to you as 'his fancy piece'. You are an established academic, with an excellent publication record which is ignored internally. Your work has been dismissed as not relevant to the work of the [predominantly white male] department. Even though you get external invitations, you are rarely asked to speak or included in internal events. (mid-career researcher)

The consequences of this type of behaviour means that women have talked of feeling isolated, personally and academically, within their own institutions, and within their wider academic field. These experiences of becoming isolated have further consequences in the impact this has on women's confidence in their own work. The women I spoke to had experiences which they felt unable to articulate not only within an institutional context, but also found difficult 
to verbalise outside of the institution. Many of the women that I interviewed felt uncomfortable in having their experiences described, even in an academic journal. They are afraid that they may be recognised, identified and targeted or be on the receiving end of subtle backlashes and micro-aggression. These experiences are difficult to prove in an evidential setting, as required by the strictures of organisational bureaucracy, but have significant impacts on day-to-day wellbeing. These experiences 'silence' women (for a wonderful history of the silencing of women, see Beard, 2017).

This silencing feeds in to the isolation that is reinforced through physical and cultural practices and experiences. In a bid to maintain anonymity for those who have spoken to me, the following contains a combination of interviews, interweaved in to one narrative account:

The touching, and suggestive nature of the senior colleague makes you uncomfortable. You have organised events, where he positions himself as your co-author (even though he is not) and will upstage sessions claiming they were his idea. You have to continue to put up with this, as he is the departmental Head. This means he controls the budget strings, is able therefore to decide which conference you can go to or not. He is responsible for setting workloads. You have seen him 'punish' other female colleagues in the past for refusing his advances, by denying their budgets, increasing their teaching and pastoral hours, in a way that does not happen with male colleagues. He hangs round your door, makes leery comments. You have been asked why you go along with this, why you allow him to do it. But that is to miss the point. Where do you go with this? You saw another female colleague be the victim of a serious (and untrue) allegation by a student. However, this colleague was summoned to the office of the department head. There she was shouted at by the male Head of Department, and the male teaching team lead. Both of these men were White (your female colleague is Black). When she tried to give her side of the story, she was shouted at and told not to be aggressive. She found herself isolated with nowhere to turn. Not only are senior managers predominantly male, but they are also predominantly white. We have seen time and time again, power structures close in, as white male privilege reasserts itself.

There are a number of disturbing aspects to these stories. Here we see women academics 'disciplined and punished' (cf. Foucault, see also King, 2004) for speaking out about experiences. Cultures of silencing women and women being silenced have historical roots. We know that women are less likely to speak but have their ideas appropriated by men, and 
this is rooted historically (Beard, 2017). When they do speak, they are more likely to face a backlash not only for speaking more than men, but for speaking out (Brescoll, 2011). These 'norms' of women being silenced are linked not only to individual women themselves. The subjugation of women relies on both a social system which is constructed upon perceived differences between men and women based on biological difference, which has been reinforced through the history of Western thought (Beard, 2017; King, 2004: 31). The silencing of women explicitly (through the phenomenon now referred to as 'mansplaining' [attributed to the work of Solnit, 2014]) or implicitly through reinforcing gendered power structures has an impact. Constructing our social and knowledge systems along this biological dualism is also evident in the ways in which knowledge is constructed. Western thought located in mind/body dualism reinforces these biological differences where 'Man is mind and represents culture: the rational, unified, thinking subject; woman is body and represents nature: irrational, emotional and driven by instinct and physical need' (King, 2004: 31). The rational thinking subject is of course consistent with the neoliberal individual. Where women are biologically and epistemologically conceived as emotional, negates, marginalises and silences their claims to knowledge. This translates into women being penalised for speaking:

Senior managers seem to close ranks. You had previously told a senior woman about your concerns, she tried to do something and speak generally to senior managers. She herself was penalised for this, ostracised and put in a precarious position by managers who labelled her as a trouble maker. You just *know* that you cannot go to the senior managers, who you see protect each other. This makes you afraid to speak out. (early career researcher)

It also internalises the silencing mechanism:

However hard you try, there is always a part of you that thinks, what if they are right, what if you are not good enough, what if you can't do this You don't have anyone you can talk to about this and often think about leaving the profession, it can't be this bad in other sectors can it? (early career researcher).

Women are deterred from complaining and so they turn inwards and internalise the cultural violence enacted here. This can result is a loss of confidence and the internalisation of the negative reaction and the misogyny. 


\section{Internalising misogyny}

When you receive complaints at the student committee, that are taken seriously and recorded on University documentation, from students who complain about the skirts you are wearing because they are old fashioned (female academic near retirement)

When we see a young woman, and assume she is a secretary rather than an academic, or we assume the Professor is male, when the focus is on a female academic's dress or her 'anger' rather than her work; these are instances of internalised misogyny. And the awareness of this perhaps renders clear to us how deep-rooted this issue is. Internalised misogyny is an inherent feature of cultural sexism; and enables us to reflect upon the ways in which hegemonic masculinity is sustained. For Szymanski et al (2009: 103) internalised misogyny consists of three dimensions: devaluing of women; distrust of women; and gender bias that favours men. In essence, internalised misogyny is the involuntary internalisation by women of the sexist messages and cultural norms that circulate within our society. These norms and values teach women that they are there to be looked at and objectified (Fredrickson \& Roberts, 1997) and are manifest in a passive acceptance of traditional gender roles as well as a denial of the structural, cultural or individual levels of sexism (Bargard \& Hyde, 1991; Downing \& Roush, 1985; Fischer et al, 2000; Moradi \& Subich, 2002). In this psychological literature the internalisation of these norms are a source of women's distress. Recognising this internalised misogyny does not automatically free us of it. Internalised misogyny for example can lead women to conform to the expectation that they must smile at, and be pleasing to, men (for an interesting discussion about this social expectation see Ahmed, 2017).

This internalisation of misogyny is rendered explicit through female expectations of first, what a lecturer should look like, (male, and white) and second, what a woman should be concerned with (clothes rather than knowledge). And here perhaps again, we see the effects of internalised misogyny being documented, not challenged, in institutional records. 
Women have historically been positioned with the academy as teachers (Prentice and Theobold, 1991), rather than 'serious researchers' with teaching widely seen as 'a feminine activity' (Brabazon, 2014: 55). Historically, men who teach have been defined as 'Masters' (Epstein, 1981) and we see this assumption permeate contemporary internalisations of this assumption in student evaluations. An online tool demonstrates how women are more likely to be judged negatively in student evaluations (benschmidt.org; 2015). Using data from 14 million student reviews, Schmidt's tool shows us how words such as 'intelligent', 'smart', 'clever' are much more likely to be included to describe men, than women, academics; women are more likely than their male counterparts to be described as irritating, annoying or a bad teacher (which of course can have consequences for promotion or tenure). At the same time, women are more often described as 'supportive' or 'caring' than men, which simply serves to reinforce traditional gender stereotypes of women playing a pastoral role. Similarly, women were more likely than men to be referred to in terms of their appearance as 'stylish' (or not!)

When a female student derides your lectures, says they are not as intelligent as your male counterparts; her understanding of what a lecturer looks like is male and your tutoring you are told is 'wasting her money'. (mid career academic)

When you are a new female Professor and are asked by a male lecturer, oh are you the new secretary, on introduction. (newly-appointed Professor)

Or as Heidi Mirza (2006:106) has described it when you are 'mistaken for the coffee lady'. These comments rely on the assumption of 'normal' gender roles within a University context. This kind of casual remark situated in a cumulative context, further serves to reinforce the hegemonic view of the white male Professor as the norm, the female Professor as culturally 'other'. This notion of 'what an academic looks like' is something that is often reinforced not only through direct experience but visually, culturally around the institutions in which we are located in. 
When you are waiting to see the Vice Chancellor and his lobby is full of pictures of white men, and their achievements. You ask where am I in this institution? In the recognition of achievements? (senior lecturer)

This internalisation is powerful. Not only does it have an impact on the individual woman on the receiving end of such responses but it also reinforces that neoliberal hegemonic masculine climate, whereby these dominant interests limit the opportunities for women. If women are not viewed as 'serious' academics, their contributions devalued, or demeaned, then this also reduces their capacity to compete in the job market. As Brabazon wryly observes 'there are few strategies in life like sexism that can remove $50 \%$ of the competitors for a particular job' (Brabazon, 2014: $57 \mathrm{fn}$ ) or indeed promotion opportunity.

Assumptions of character traits, visible in the neoliberal hegemonic model, also feed into perceptions of 'fit' for roles. Spangsdorf's (2016) research highlights the ways in which perceptions of traits are still inherently gendered, and traits which are individualistic are prized more highly in senior positions. What is notable is that not solely are these traits consistent with the requirements of neoliberalism - 'competitiveness', 'self-reliance' and 'being forceful' are viewed as necessary for leadership - but that these traits which are viewed as the properties of men (Cuddy et al, 2015). The implicit desirability of these traits is also bound up with the merit argument.

You argue that you need more female staff in an all-white male department. But you are shouted down, and told that you are being ' $p c^{\prime}$ ' and that there was no place for that in our department, what we should be looking for is the best man for the job. There was no sense of irony in the use by the department chair of the word man, rather than person! (male mid-career academic)

Here, 'merit' is seen as the only feature by which one should be promoted or appointed. But again, the merit argument plays straight in to the neoliberal hegemonic masculinity ideal: it is individualistic in its focus. In denying the structural context we also deny the structural advantages afforded historically where the 'rules of the game' have been determined by white men. What 'merit' often means in these contexts is looking around at the status quo: 'who is 
already in these roles, what do they look like?' Contesting neoliberal white hegemonic masculinity means acknowledging that there is value in difference.

\section{Conclusion: A manifesta}

In this article I have argued that 'cultural sexism' is situated within and contingent upon a context that is characterised by neoliberal hegemonic masculinity. Cultural sexism is operationalised through women's isolation; their disciplining and silencing; and through the internalisation of misogyny. But as with all critical approaches, the argument is not just that we attempt to understand the world, but that we wish to change it. As such, but way of conclusion, we might then ask, given this context how do we navigate the environment imposed by cultural sexism in practice? How might we challenge this white hegemonic neoliberal masculine terrain?

In Living a Feminist Life, Sara Ahmed (2017), noting that it is not always easy to live as a feminist, provides a series of coping strategies. And it is inspired by her, and the experiences of the many women I have interviewed and spoken with, that I propose this manifesta:

1. As Sara Ahmed (2017) argues, to name the problem is not to be to blame for the problem. Speak up and discuss the issues and the problems. Tell someone what is happening to you, tell someone you trust. It doesn't have to be your line manager, or someone in your department, the key is that you trust that person;

2. Build your power bases, if you are surrounded by people offering and providing support it is more difficult to be targeted or feel isolated; 
3. Be visible - grow your reputation externally and internally, and within this you will find people who will support and look out for you. It will also help prevent you becoming isolated;

4. Don't internalise the negative assumptions made about you. Academic work is peerreviewed. It is the peer-reviewer, and wider academic community who is the judge of your academic research, not your immediate male colleagues;

5. Recognise your privilege. Our culture and society rely on the privileging of white, heterosexual, neoliberal cis gender masculinity. In those structures, we have a responsibility to speak up for those who are structurally disadvantaged and not in the room, or do not have a voice or seat at the table;

6. Actively ensure you cite other women in your work;

7. Think about women who you can invite as speakers, as role models, and the Feminist Philosophers' blog (2011) provides a handy checklist to pass on to colleagues organising events that might be in danger of becoming male only;

8. Listen to women's experiences, hear them, experience them and look for ways to offer support (and do not mansplain!).

\section{References}

Acker, J (1992) 'From Sex Roles to Gendered Institutions' Contemporary Sociology 21 pp565569

Ahmed, S (2017) Living A Feminist Life (Durham: Duke University Press)

Allen, W.R. (1992) 'The color of success: African-American college student outcomes at predominantly White and historically Black public colleges and universities Harvard Education Review 62 pp26-44

Amery, F., Bates, S., Jenkins, L., \& H. Savigny (2015) 'Metaphors on Women in Academia. A review of the literature 2004-2013' in eds. V. Demos \& M. T. Segal At the centre: Feminism, Social Science and Knowledge (Advances in Gender Research, Volume 20) Emerald Group Publishing Limited, pp.245-267 
Armato, M (2013) 'Wolves in Sheep's Clothing: Men's Enlightened Sexism \& Hegemonic Masculinity in Academia' Women's Studies 42:5 pp578-598

van den Brink, M \& Benschop, Y (2012) 'Slaying the seven-headed dragon: The quest for gender change in academia' Gender, Work \& Organisation 19 (1) pp71-92

Bargad, A., \& Hyde, J. S. (1991). Women's studies: A study of feminist identity development in women. Psychology of Women Quarterly 15, 181-201

Beard, M (2107) Women and Power. A Manifesto (London: Profile Books Ltd)

Becker \& Swim (2011) Seeing the Unseen. Attention to Daily Encounters With Sexism as Way to Reduce Sexist Beliefs Psychology of Women Quarterly 35 (2) pp227-42

Benschop, Y. and Brouns, M. (2003) 'Crumbling Ivory Towers: Academic Organizing and its gender effects' Gender, Work and Organization 10 (2) 194-211.

Bird, S. R (2011) 'Unsettling Universities' Incongruous, Gendered Bureaucratic Structures: A Case Study Approach' Gender, Work and Organization 18 (2) pp202-30

Bothwell, E (2017) Female leadership advances slowly in world's top universities Times Higher Education August 16 https://www.timeshighereducation.com/news/femaleleadership-advances-slowly-in-worlds-top-universities

Bothwell, E (2016) Black female professor feels role models 'required' for BME students Times Higher Education https://www.timeshighereducation.com/news/black-femaleprofessor-feels-role-models-required-bme-students (accessed 27/10/17)

Brabazon, T (2014) Maybe He's Just Better Than You": Generation X Women and Higher Education Journal of Women's Entrepreneurship and Education 3-4 pp48-70

Brescoll, V. L (2011) Who Takes the Floor and Why. Gender, Power, and Volubility in Organizations Administrative Science Quarterly 56 (4) pp622-41

van den Brink, M., and Y. Benschop. 2012. "Slaying the Seven-headed Dragon: The Quest for Gender Change in Academia." Gender, Work \& Organization 19 (1): 71-92.

van den Brink, M., and L. Stobbe. 2009. "Doing Gender in Academic Education: The Paradox of Visibility." Gender, Work \& Organization 16 (4): 451-470.

Butler, J (1999) Gender Trouble (New York: Routledge)

Carrigan, T., B. Connell. and J. Lee (1987) 'Toward a New Sociology of Masculinity' in H. Brod. Ed. The Making of Masculinities: The New Men's Studies (Boston: Allen and Unwin) pp65-80

Collini, S (2012) What are Universities for? (London: Penguin)

Connell, R (1983) Which Way is Up? Essays on Class, Sex and Culture (Sydney: George Allen and Unwin)

Connell, R. (1995) Masculinities (Sydney: Polity Press).

Crenshaw, K (1991) Mapping the Margins: Intersectionality, Identity Politics, and Violence against Women of Color Stanford Law Review 43 (6) pp1241-99 
Cuddy, A.J.C., Wolf, E.B., Glick, P., Crotty, S., Chong, J. \& Norton, M.I. (2015). Men as Cultural Ideals: Cultural Values Moderate Gender Stereotype Content. Journal of Personality and Social Psychology, 109 (4), pp. 622-635

De Beauvoir, S (1997) The Second Sex (London: Vintage)

Doherty, T (2011) For the University (Bloomsbury)

Donaldson, M (1993) What is hegemonic masculinity? Theory and Society 22 (5) pp643-57

Downing, N., \& Roush, K. (1985). From passive acceptance to active commitment: A model of feminist identity development for women. The Counseling Psychologist 13, 695-709

Epstein, J (1981) Masters: portraits of great teachers (New York: Basic Books)

Eveline, J. and Booth, M. (2004) 'Don't write about it': Writing 'the other' for the ivory basement. Journal of

Organizational Change Management, 17,3, 243-55.

Feminist Philosophers (2011) How to avoid a gendered conference

https://feministphilosophers.wordpress.com/2011/03/26/how-to-avoid-a-genderedconference/

Ferber, M.A. (1988) Citations and networking Gender and Society 2 (1) pp82-89

Fredrickson, B. L., \& Roberts, T. (1997). Objectification theory: Toward understanding women's lived experiences and mental health risks. Psychology of Women Quarterly 21, 173-206

Gill, R (2009) 'Breaking the silence: The hidden injuries if neoliberal academia' in R. Flood \& R. Gill (eds) Secrecy and silence in the Research Process: Feminist Reflections (London: Routledge)

Gill, R \& Donaghue, N (2016) 'Resilience, apps and reluctant individualism: Technologies of self in the neoliberal academy' Women's Studies International Forum 54 pp91-9

Gill, R (2017) Beyond individualism: the psychosocial life of the neoliberal university' in M. Spooner (ed) A Critical Guide to Higher Education \& the Politics of Evidence: resisting Colonialism, Neoliberalism \& Audit Culture (Regina, Canada: University of Regina Press)

Gledhill, C (1997) 'Genre and Gender: The case of soap opera' in (ed.) S. Hall Representation: Cultural Representations and Signifying Practices (London: Sage) pp337-84

Grove, J (2013) “Global Gender Index, 2013," Times Higher Education May 2, https://www.timeshighereducation.com/features/global-gender-index-

2013/2003517.article

hooks, b (1981) Ain't I A Woman (Boston: South End Press)

Higher Education Statistics Agency (2014) Statistical First Release 209 - Staff at HE Providers in the United Kingdom 2013/14 (December 18, 2014).

Higher Education Statistics Agency (2017) Staff at higher education providers in the United Kingdom 2015/16 $19^{\text {th }}$ January https://www.hesa.ac.uk/news/19-01-2017/sfr243-staff accessed 31/1/18

Jenkins, K (2014) 'That's not philosophy': feminism, academia and the double bind Journal of Gender Studies 23 (3) pp262-74 
Khan, C (2017) Do universities have a problem with promoting their BAME staff? The Guardian https://www.theguardian.com/higher-education-network/2017/nov/16/douniversities-have-a-problem-with-promoting-their-bame-staff? $16^{\text {th }}$ November

King, A (2004) The Prisoner of Gender: Foucault and the Disciplining of the Female Body Journal of International Women's Studies 5 (2) pp29-39

Klein, N (2007) The Shock Doctrine (Toronto: Random House)

Knights, D \& Richards, W (2003) 'Sex Discrimination in UK Academia' Gender, Work \& Organisation $10(2)$ pp213-38

Leonard, D (2001) A woman's guide to doctoral studies (Buckingham: Open University Press)

Longino, H. (2010) 'Feminist Epistemology at Hypatia's 25th Anniversary' Hypatia 25 (4) 733-41.

Lorenz, C (2012) 'If You're So Smart, Why Are You under Surveillance? Universities, Neoliberalism, and New Public Management' Critical Inquiry 38 (3) pp599-629

Maliniak, D., Powers, R. \& B. F. Walter (2013) The Gender Citation Gap in International Relations International Organisation 67 (4) pp. 889-922

Mirza, H (2006) Transcendence over Diversity: Black women in the academy Policy Futures in Education 4 (2) pp101-113

Mirza, H. S (2017) ' "One in a million": A journey of a post-colonial woman of colour in the White academy' in eds. D. Gabriel \& S.A Tate Inside the Ivory Tower (London: Trentham Books)

Moradi, B., \& Subich, L. M. (2002). Perceived sexist events and feminist identity development attitudes: Links to women's psychological distress. The Counseling Psychologist $30,44-65$

Murray, R (2014) Quotas for Men: Reframing Gender Quotas as a Means of Improving Representation for All American Political Science Review 108 (3) pp520-32

Parsons, E \& Priola, V (2013) 'Agents for Change and Changed Agents: The micro-politics of change ad feminism in the Academy' Gender, Work \& Organization 20 (5) pp580-97

Park, S.M. (1996) 'Research, teaching and service: why shouldn't women's work count?' Journal of Higher Education,

67 (1) 46-84.

Patton, T. O (2004) 'Reflections of a Black Woman Professor: Racism and Sexism in Academia' Harvard Journal of Communications 15 pp185-200

Pereira, M do Mar (2017) Power, Knowledge and Feminist Scholarship: An Ethnography of Academia (London: Routledge)

Runnymede Trust (2015) Black Students Must do Better than White Students to get into University $3^{\text {rd }}$ February https://www.runnymedetrust.org/news/594/272/Black-StudentsMust-do-Better-than-White-Students-to-get-into-University.html

Sandberg, S (2013) Lean In (New York: Alfred A Knopf/Random House)

Sang, K (2016) Gender, ethnicity and feminism: an intersectional analysis of the lived experiences feminist academic women in UK higher education Journal of Gender Studies pp1-15 
Savigny, H (2014) Women, know your limits: cultural sexism in academia Gender and Education 26 (7) pp794-809

Savigny, $\mathrm{H}$ (2017) Cultural sexism is ordinary: writing and re-writing women in academia Gender, Work \& Organisation forthcoming

Schmidt, B (2015) Gendered Language in Teacher Reviews http://benschmidt.org/profGender/

Scullion, R. and Molesworth, M., (2016) Normalisation of and resistance to consumer behaviour in higher education. Journal Of Marketing For Higher Education 26 (2), 129-131.

Solanke, I (2017) Black Female Professors in the UK Runnymede Trust March 2017 https://www.runnymedetrust.org/uploads/BlackFemaleProfessorsMarch2017.pdf

Solnit, R (2014) Men Explains Things to Me and Other Essays (Chicago: Haymarket Books)

Spangsdorf, S (2017) We don't see women as leaders - and it's holding them back in our universities The Guardian 22 ${ }^{\text {nd }}$ December https://www.theguardian.com/higher-educationnetwork/2017/dec/22/we-dont-see-women-as-leaders-thats-why-so-few-are-universitychiefs

Spangsdorf, S (2016) The Glass Slipper Effect: The influence of occupational identity by association on the motivation to pursue a top managing position among women in Denmark University of Liverpool Research paper http://spangsdorf-

staal.dk/The_Glass_Slipper_Effect_2016_danske\%20kvinder_identitet_topledelse.pdf

Szymanski, D. M., Gupta, A., Carr, E. R. \& D. Stewart (2009) Internalized Misogyny as a Moderator of the Link between Sexist Events and Women's Psychological Distress Sex Roles 61 pp101-09

Weale, S (2016) UK's university gender gap is a national scandal, says thinktank The Guardian $12^{\text {th }}$ May https://www.theguardian.com/education/2016/may/12/universitygender-gap-scandal-thinktank-men

Women's Aid (2018) The Femicide Census. Annual Report $201718^{\text {th }}$ December 2018.

https://1q7dqy2unor827bqjis0c4rn-wpengine.netdna-ssl.com/wpcontent/uploads/2018/12/Femicide-Census-of-2017.pdf

World Health Organization (2017) Violence Against Women $29^{\text {th }}$ November https://www.who.int/news-room/fact-sheets/detail/violence-against-women

Wright, T (2014) Whatever happened to the F word in higher education? Journal of Gender Studies 25 (2) pp215-227

Yong, E (2017) Women Are Invited to Give Fewer Talks Than Men at Top U.S. Universities The Atlantic December $18^{\text {th }}$ https://www.theatlantic.com/science/archive/2017/12/womenare-invited-to-give-fewer-talks-than-men-at-top-us-universities/548657/ 
